\title{
Analyzing Electronic Customer Relationship Management (e-CRM) Performance of Public Sector Banks in Chennai City
}

\author{
Dr.M.Vidya ${ }^{1}$, Dr.R.Shanthi² \\ ${ }^{1}$ Assistant Professor of Commerce(SS), The Tamil Nadu Dr. Ambedkar Law University, Chennai-113. \\ ${ }^{2}$ Associate Professor of Commerce, Department of Commerce, University of Madras, Chennai-5.
}

\begin{abstract}
The present empirical study was aimed to explore the perception of public sector bank customers with respect to e-CRM practices followed in the Indian Banking context. This study adopted survey method and collected primary data from public sector bank customers residing in Chennai city alone. The statistical tools such as frequency distribution, one-way analysis of variance, correlation and multiple regression analyses have been applied to draw the feasible solutions to the research problem. The result of the study proves that e-CRM is very important key factor for improvement of performance in public sector banks with positive impact. It is suggested in the study to adopt innovative, imperative, effective and enriched e-CRM practices will help the public sector banks to increase their customer base and this in-turn increases the performance of the banks in the study area.
\end{abstract}

\section{Keywords}

E-CRM, Banking, Performance, Perception, Service Quality and Internet Driven Channel

Article Received: 18 October 2020, Revised: 3 November 2020, Accepted: 24 December 2020

\section{Introduction}

The e-CRM system is used to sustain a good relationship with their customers by providing the facilities of advanced technological benefits and the maintenance of higher security control to the customers. CRM involves the complete scrutiny and practice of the knowledge among customers' to sell products and services (Ling \& Yen, 2001; Hong kit Yim., \& et al., 2004). The prominent goal of the companies in adopting the e-CRM system is to improve the service to the customer, develop a good relationship and to retain the valuable customers with the company through the digital channels (Xu., \& et al., 2002; Karakostas, \& et al., 2005). The effective quality of service support was the key to improve the retention rate of the customers and even to maintain a good customer relationship (Lee, \& et al., 2001; Leventhal, \&
Zineldin 2006). In today's competitive environment, the company pays more attention in order to fulfil the needs of customers more through digital platforms (Van Weele, \& Rozemeijer 1996). An increasing number of various companies are implementing the e-CRM system aim to be satisfy the growing expectation of the customer service (Pan, \& Lee 2003; Azila., \& Noor Neeraj, 2011; Anderson, 2001). The e-CRM system has the unique characteristics which support the customer -business interaction (Pan, \& Lee 2003) and the system across different areas for operational and analytical purposes (Grover, 2011; Xu, \& Walton 2005). The competition in the market is forcing the corporations to differentiate themselves from their rivals by providing specialized and effective services to their customers. The digital transformation of technology practices is 
enhancing an imperative strategy of organisation create a competitive advantage both internal and external (Kennedy, 2006), the usage of e-CRM practices is to forge a long-term relationship with their customers through the modern information technology platforms (Wu, \& Wu K., 2005; Kimiloglu, \& Zarali 2009; Paryne \& Frow 2013).

\section{E-CRM IN BANKING INDUSTRY}

"Banks are adopting modern technology to develop an innovative customer's solution to attain the growth and profitability with the framework of sound management practices (Bantel, \& Jackson, 1989; Slater, \& Mohr 2006)". The banks are tapping into the online services to initiate a new era in customer relationship management to create an effective one to one relationship in order to enhance the competitive advantage (Peppard, 2000; Mittal, \& Kumra, 2001; Gebert, \& et al., 2003). The rapid development of the technology and the globalization encourages the customers to improve (Ashford \& Hall 2011; Stefanou, \& et al., 2003) and adapt to the technological benefits provides greater interaction and participation in the sustainability of the banks in the future (Balachandra \& et al., 2010; Mnjala, 2014). E-CRM is referred to as the web-based CRM done to manage the customer interactions over the web process which exploits the power of the internet (Cho, Y \& et al., 2002). E-CRM system enables the business to interact with customers at high speed (Xu, \& Walton 2005) and more reliable on the system as it's highly secured from the threats (Romano \& Fjermested 2007; Darajeh \& Tahajod, 2010; Harrigan, \& et al., 2012). All the commercial banks maintain a good relationship with the customers (Das, 2012) by providing effective product and services according to the need of the customers through the e-CRM techniques by the digital forms (Pan \& Lee, 2003; Abu-Shanab, \& Anagreh 2015; Chopra \& et al., 2012). E-CRM facilitates easy customer interaction with the banks which leads to the satisfaction of the services provided to the customer (Khare, 2010; Chen \& Popovich 2003; Dhingra, \& Dhingra V 2013; Mittal, \& Kumra, 2001). The interaction process includes the three major factors which the information exchanges, business or financial transaction and social exchange (Zineldin, 1995). The customers are benefited through speedy processing of the bank transaction through the e-response to them (Dhingra, \& Dhingra, 2013). Trust and convenience are the major benefits which are provided through the e-CRM system to the customer of the banks (Abu-Shanab, \& Anagreh, 2015; Khare, 2010). E-CRM system maintains improved security for the customers. The increasing rate of accuracy of the transaction involved through the e-CRM reflects the improvement of the service quality by the banking sector.

\section{REVIEW OF LITERATURE}

Jasveen Kaur \& Baljit Kaur (2016) the study attempts to highlights the effectiveness of e-CRM practices and performance of e-CRM. The researcher were adopted a self administrated questionnaire in order to collect the data through a purposive sampling technique. Finally, the researchers have concluded that the e-CRM practices is significantly influencing the banking sector financial performances and it enhancing the organisation to make effective strategies for execute the competitive advantage.

Rashid Farroqi \& et al., (2013) the purpose of the study was to create new business opportunities by identifying and understanding the need through giving a prior importance to the customers. The conceptual study was adopted to explore the trend of e-CRM in commercial banks of India in the recent past. The study depicts the process of the orgnaisation which enhances the traditional definition of the e-CRM marketing concepts and objectives of the commercial banks. The authors suggest that bank should adopt the e-CRM customer centric approach, as the internet banking was widely accepted by the customers. The study concludes that the e-CRM system in digital 
platforms should create a brand image on the safety of the customers money transaction through a proper security protection by the commercial banks.

Sandeep Walunj \& Barhate (2014) the study explores on the concepts of e-CRM in Indian banks from the various dimension of techniques and benefits processed through the e-CRM. The authors has identified the various techniques which includes ATMs, phone banking, internet banking/e-banking, electronic fund transfer which helps the banks in retaining the present customers, attracting the fresh customers and providing services through various techniques to satisfy the customers. The researchers suggest that the success of e-CRM depends on the development of the bank robust and flexible infrastructure. The author recommends that retail customer, trade and industry sector and corporate sector to avail the e-CRM practices for the banking transaction requirements. The study concludes that the e-CRM helps in understanding needs and wants of the customers to provide the effective services to satisfy the users.

Chandra Hendriyani \& Sam'un jaja (2018) the study illustrate the forms of e-CRM for developing the customer engagement in the banking sector. The result indicates that the internet technology in banking sector reflects a significant positive relationship which pursues the sustainability. The study concludes that implementation of the e-CRM provides solutions for the customer's problems as internet offers bank and customers in relations of increasing the productivity and reducing costs. The author suggests that the e-CRM need to increase customer loyalty to create a bonding with effective customer engagement.

Greeshma (2016) the purpose of the study was to understand the benefits of the customers in ICICI bank on e-CRM initiative. The main objective of the study was to explore the satisfaction level of the exit services and to identify the problems confronted by the customers of ICICI bank services provided. The researcher adopted an empirical study and the result reveals that the proper e-CRM practices will improved the relationship with the customers and helps to increase the customer satisfaction through the effective management of the provided information. The findings of the study indicate that e-CRM initiatives reduce the cost of production and increase the customer loyalty through an improved relationship with customers.

Navimipour N J \& Soltani Z (2016) have aimed to be discussed the determinants o e-CRM practices towards the effective business performance. The author have explored that the technology acceptance in the organization performance enhancing the infrastructure capability, e-learning process and ease of use dimensions are positively and significantly influences on the effectiveness towards e-CRM. Finally, researchers have concluded as the cost, technology acceptance and satisfied employee's plays a significant role towards the effectiveness on e-CRM in business performance.

\section{NEED FOR THE STUDY}

Electronic customer relationship management comprises of all the functional activities with the help of internet, intranet and extranet. Due to the growth of internet and its usage among all type of customers makes every business firm and organisations to move towards the adoption of internet connectivity for their better maintenance. Todays' customers are not afraid to use informational technology devise in their day-to-day life due to exposure and availability of opportunities in the market. Market conditions are hypercompetitive in recent scenario, so, it is very imperative to adopt better and updated methods to attract as well as to retain the existing customers in their business. Further, eCRM is more helps from new product development to 
decline of the product were consumers plays a very important role to play for the success of the any product or service. This study is need of the hour to explore the potential opportunities in market with respect to electronic customer relationship management.

\section{AIMS OF THE STUDY}

This study aims to explore the difference between age group of the respondents towards the number of visit to the bank and the number of online transactions in a month. Further, this study attempt to measure the perception of customers about e-CRM practices in public sector banks, employees service quality, information trust, customer satisfaction and e-CRM performance with reference to educational qualification of the respondents. Finally, to suggest measures to improve the e-CRM performance in public sector banks.

\section{METHODOLOGY}

This study was basically empirical and descriptive in nature and both quantitative cum qualitative data were studied in the present study to explore public sector bank customers perception with respect to E-CRM performance in the study area. The non-probability sampling techniques were adapted to select group of respondents from the overall population of the study. The sample size 150 were finalised and subjected to analysis using SPSS Version 16.0 for the purpose of solving the research problem of the study. The statistical tools such as frequency distribution, one way analysis of variance (ANOVA), correlation and multiple regression analysis has been applied to draw meaningful finding for the study.

The structured questionnaire was finalised after the conduct of pilot study and pre-testing. The survey method was adopted to collect the perception of public sector bank customer in the study area. The questionnaire started with demographic characteristics of the respondents and ended with variable specific questions related to the perception e-CRM practices profile, followed by variable measuring the e-service quality, employees quality of their service, information trust, customer satisfaction and performance of e-CRM practices towards the public sector banks are measured by using the five point Likert scale “(1 - Strongly Disagree to 5 - Strongly Agree $)$ ".

\section{RESULT AND DISCUSSION}

The Cronbach's alpha reliability statistical test has been applied to measure the internal items consistency. The Cronbach's Alpha Validity test result explore that 0.886 of overall dimension for this study and which indicates high credibility of internal structure design questionnaire. It is shown in table 1.

Table 1: Results of Reliability Analysis

\begin{tabular}{|l|c|c|}
\hline \multicolumn{1}{|c|}{ Study variables } & $\begin{array}{c}\text { No. of. } \\
\text { Items }\end{array}$ & $\begin{array}{c}\text { Alpha } \\
\text { co-efficient }\end{array}$ \\
\hline e-Service Quality & 5 & 0.625 \\
\hline $\begin{array}{l}\text { Employees } \\
\text { Service Quality }\end{array}$ & 9 & 0.750 \\
\hline $\begin{array}{l}\text { Information } \\
\text { Trust }\end{array}$ & 4 & 0.663 \\
\hline $\begin{array}{l}\text { Customer } \\
\text { Satisfaction }\end{array}$ & 5 & 0.647 \\
\hline $\begin{array}{l}\text { e-CRM } \\
\text { Performance }\end{array}$ & 53 \\
\hline
\end{tabular}

Based on the results of Cronbach's Alpha statistical test, the survey instruments were finalised. The questionnaire for this study were consisting the two parts. Part 1: Demographic and perception of e-CRM profile and Part 2: Practices of E-CRM dimensions.

Table 2: Respondents Demographic Profile

\begin{tabular}{|c|c|c|c|}
\hline Variables & $\begin{array}{c}\text { No. of } \\
\text { Responden } \\
\text { ts }(\%)\end{array}$ & Variables & $\begin{array}{c}\text { No. of } \\
\text { Responden } \\
\text { ts }(\%)\end{array}$ \\
\hline
\end{tabular}




\begin{tabular}{|c|c|c|c|}
\hline \multicolumn{2}{|c|}{ Age } & \multicolumn{2}{|c|}{$\begin{array}{l}\text { Educational } \\
\text { Qualification }\end{array}$} \\
\hline $\begin{array}{l}\text { Below } \\
25 \text { years }\end{array}$ & $40(26.7)$ & $\begin{array}{c}\text { School } \\
\text { education }\end{array}$ & $9(6)$ \\
\hline $\begin{array}{l}25 \text { years - } \\
35 \text { years }\end{array}$ & $71(47.3)$ & Graduate & $68(45.3)$ \\
\hline $\begin{array}{c}36 \text { years - } \\
45 \text { years }\end{array}$ & $26(17.3)$ & $\begin{array}{c}\text { Post } \\
\text { Graduate }\end{array}$ & $44(29.3)$ \\
\hline $\begin{array}{c}46 \text { years }- \\
55 \text { years }\end{array}$ & $9(6)$ & $\begin{array}{c}\text { Profession } \\
\text { al }\end{array}$ & $17(11.3)$ \\
\hline $\begin{array}{c}\text { Above } 55 \\
\text { years }\end{array}$ & $4(2.7)$ & Diploma & $12(8)$ \\
\hline \multicolumn{2}{|c|}{ Gender } & \multicolumn{2}{|c|}{ Marital Status } \\
\hline Male & $70(46.7)$ & Married & $80(53.3)$ \\
\hline Female & $80(53.3)$ & $\begin{array}{c}\text { Unmarrie } \\
\mathrm{d}\end{array}$ & $70(46.7)$ \\
\hline \multicolumn{2}{|c|}{ Occupation } & \multicolumn{2}{|c|}{ Monthly Income } \\
\hline Student & $43(28.7)$ & $\begin{array}{c}\text { Less than } \\
20,000\end{array}$ & $37(24.7)$ \\
\hline $\begin{array}{c}\text { Governme } \\
\text { nt } \\
\text { Employee }\end{array}$ & $24(16)$ & $\begin{array}{c}20,000- \\
30,000\end{array}$ & $37(24.7)$ \\
\hline $\begin{array}{c}\text { Private } \\
\text { Employee }\end{array}$ & $46(30.7)$ & $\begin{array}{l}30,000- \\
40,000\end{array}$ & $26(17.2)$ \\
\hline Business & $24(16)$ & $\begin{array}{c}40,000- \\
50,000\end{array}$ & $25(16.7)$ \\
\hline Others & $13(8.6)$ & $\begin{array}{l}\text { Above } \\
50,000\end{array}$ & $25(16.7)$ \\
\hline \multicolumn{2}{|c|}{ Type of Bank Account } & \multicolumn{2}{|c|}{$\begin{array}{l}\text { No.of.Visit to the Bank } \\
\text { in a Month }\end{array}$} \\
\hline $\begin{array}{l}\text { Savings } \\
\text { Account }\end{array}$ & $102(68)$ & 1-2 times & $46(30.7)$ \\
\hline $\begin{array}{c}\text { Loan } \\
\text { Account }\end{array}$ & $11(7.3)$ & 3-4 times & $74(49.3)$ \\
\hline $\begin{array}{l}\text { Recurring } \\
\text { Deposit }\end{array}$ & $6(4)$ & 5-6 times & $17(11.3)$ \\
\hline
\end{tabular}

\begin{tabular}{|c|c|c|c|}
\hline $\begin{array}{l}\text { Current } \\
\text { Account }\end{array}$ & $28(18.7)$ & \multirow{2}{*}{$\begin{array}{l}\text { More than } \\
6 \text { times }\end{array}$} & \multirow{2}{*}{$13(8.7)$} \\
\hline $\begin{array}{c}\text { Joint } \\
\text { Account }\end{array}$ & $3(2)$ & & \\
\hline \multicolumn{2}{|c|}{ Using Online Banking } & \multicolumn{2}{|c|}{$\begin{array}{c}\text { Transaction in the Bank } \\
\text { in a Month }\end{array}$} \\
\hline $\begin{array}{c}\text { Below } 1 \\
\text { year }\end{array}$ & $62(41.3)$ & $1-3$ times & $49(32.7)$ \\
\hline 1- 2 year & $66(44)$ & 4-6 times & $68(45.3)$ \\
\hline $3-4$ year & $21(14)$ & 7-9 times & $16(10.7)$ \\
\hline $\begin{array}{l}\text { Above } 5 \\
\text { years }\end{array}$ & $1(0.7)$ & $\begin{array}{l}\text { More than } \\
10 \text { times }\end{array}$ & $17(11.3)$ \\
\hline \multicolumn{2}{|c|}{$\begin{array}{c}\text { Banks Provide Separate } \\
\text { Enquiry Counter }\end{array}$} & \multicolumn{2}{|c|}{$\begin{array}{l}\text { Banks Charge } \\
\text { Unnecessarily }\end{array}$} \\
\hline Yes & $72(48)$ & Yes & $85(56.7)$ \\
\hline No & $43(28.7)$ & No & $32(21.3)$ \\
\hline Not aware & $35(23.3)$ & Not aware & $33(22)$ \\
\hline
\end{tabular}

From the above table majority of the respondents $(47.3 \%)$ belongs to 25 - 35 years age group, majority of the respondents were Graduates $(45.3 \%)$. The present study constitutes $53.3 \%$ female respondents and majority of the respondents were married. $30.7 \%$ of the respondents working in private organisations, majority of the respondents monthly income belongs to less than Rs. 20000 and Rs. 20000 - Rs. $30000(24.7 \%)$. Most of the respondents' were savings account holders (68\%). $49.3 \%$ of respondents were visiting the bank 3-4 times in a month. $44 \%$ of the respondents using online banking $1-2$ years. Majority of the respondents were doing approximately 4-6 transactions in a month (45.3\%). Most of the respondents (48\%) agreed that the banks provide separate enquiry counter to answer the queries of customers and $56.7 \%$ of the respondents perceived that sometimes the bank collects charges unnecessarily. 
One way analysis of variance test was conducted to know the significant difference between class means by analysing the variances with regard to e-CRM practices, e-service quality, employees service quality, information trust and performance of e-CRM. "Duncan's Multiple Range Test (DMRT) was used and it provides the level of indispensable for the difference between any pair of means, regardless of whether $F$ resulted from an initial analysis of variance".

"H0: There is no significant difference between the age group of the respondents regarding frequency of online bank transaction in a month and the number of times visited the bank in a month"

Table 3: Influence of age group on number of transactions and visit to the bank in a month

\begin{tabular}{|c|c|c|c|c|c|c|c|}
\hline & B & & & & & & \\
el & & & & Abo & & \\
& o & $25-$ & $36-$ & $46-$ & ve & F & P \\
& W & 35 & 45 & 55 & 55 & & \\
2 & 5 & & & & & \\
\hline Tran & & 1.9 & 1.9 & 2.8 & 2.50 & 2.5 & 0.03 \\
\hline No. & 1. & 1.9 & 2.1 & 3.1 & 2.50 & 5.9 & 0.00 \\
of. & 7 & $0^{\text {ab }}$ & $2^{\text {ab }}$ & $1^{\mathrm{c}}$ & bc & 10 & $0^{*}$ \\
\hline
\end{tabular}

" 1 .*denotes $1 \%$ significant level and 2 . **denotes 5\% significant level"

"3. Different alphabet between age group of the respondents denotes significant at 5\% level using DMRT test"

It can be observed from the above table that the $\mathrm{p}$ values were significant at $5 \%$ and $1 \%$ level for the two variables. The analysis was further extended with the help of DMRT and the results for number of transactions in a month explains that, the age group above 55 and 46-55 were grouped together and significantly differ in perception with other age groups. With reference to number of times visited bank in a month, the respondents from the age group 25-35 and 35- 45 were grouped together and significantly differ in the perception level of other categories. From the mean score analysis, it was identified that the respondents who belonged to the age group 46-55 and above 55 were significantly doing more number of transactions in a month and visiting bank more times in a month followed by others. Customers differ in their expectations and it is proved that the expectations differ across their age. Respondents differ in the way they approach banks for transactions. This is because of the life cycle and the requirements do differ.

Influence of educational qualification on e-CRM variables

In order to find out the mean difference between educational qualifications of respondents towards perception on e-service quality, employees service quality, information trust, customer satisfaction and performance of e-CRM practices, one way analysis of variance test was performed.

"H0: There is no significant difference between educational qualification of respondents towards perception on e-service quality, employees' service quality, information trust, customer satisfaction and e-CRM performance"

Table 4: Influence of educational qualification on e-CRM variables

\begin{tabular}{|c|c|c|c|c|c|c|c|}
\hline Study Variables & SSLC/HSC & UG & PG & Professional & Others & $\mathbf{F}$ & $\mathbf{P}$ \\
\hline \multirow{2}{*}{$\begin{array}{l}\text { Employees } \\
\text { service Quality }\end{array}$} & $3.90^{\mathrm{ab}}$ & $3.70^{\mathrm{s}}$ & $3.88^{\mathrm{ab}}$ & $3.60^{\mathrm{a}}$ & $4.26^{\mathrm{b}}$ & \multirow{2}{*}{3.66} & \multirow{2}{*}{$.007^{* x}$} \\
\hline & -0.591 & -0.506 & -0.655 & -0.402 & -0.43 & & \\
\hline \multirow{2}{*}{ E-Service Quality } & $3.60^{\mathrm{ab}}$ & $3.79^{b}$ & $3.94^{\mathrm{bc}}$ & $3.22^{\mathrm{a}}$ & $4.33^{\circ}$ & \multirow{2}{*}{6.973} & \multirow{2}{*}{$.000^{\circ}$} \\
\hline & -0.6 & -0.609 & -0.664 & -0.542 & $\begin{array}{l}-0.461 \\
\end{array}$ & & \\
\hline \multirow{2}{*}{$\begin{array}{l}\text { Customer } \\
\text { Satisfaction }\end{array}$} & $3.93^{\mathrm{ab}}$ & $3.61^{\mathrm{a}}$ & $3.74^{\mathrm{a}}$ & $3.49^{\mathrm{a}}$ & $4.23^{\mathrm{b}}$ & \multirow{2}{*}{2.975} & \multirow{2}{*}{$.021^{* *}$} \\
\hline & -0.458 & $\begin{array}{l}-0.617 \\
\end{array}$ & -0.831 & -0.442 & $\begin{array}{l}-0.488 \\
\end{array}$ & & \\
\hline \multirow{2}{*}{$\begin{array}{l}\text { Information } \\
\text { Trust }\end{array}$} & $3.63^{\mathrm{a}}$ & $3.56^{\mathrm{a}}$ & $3.85^{\mathrm{ab}}$ & $3.47^{\mathrm{a}}$ & $4.27^{b}$ & \multirow{2}{*}{3.472} & \multirow{2}{*}{$.010^{* *}$} \\
\hline & -0.626 & -0.701 & -0.866 & -0.491 & -0.47 & & \\
\hline \multirow{2}{*}{$\begin{array}{l}\text { E-Crm } \\
\text { performance }\end{array}$} & $3.91^{\mathrm{ab}}$ & $3.62^{\mathrm{a}}$ & $3.75^{\mathrm{ab}}$ & $3.65^{\mathrm{a}}$ & $4.20^{\mathrm{b}}$ & \multirow{2}{*}{1.917} & \multirow{2}{*}{0.111} \\
\hline & -0.656 & -0.634 & -0.884 & -0.478 & -0.546 & & \\
\hline
\end{tabular}

" $1 . *$ denotes $1 \%$ significant level and $2 . * *$ denotes 5\% significant level"

“3. Different alphabet between educational qualification of the respondents denotes significant at 5\% level using DMRT test"

It can be understood from the above table the $\mathrm{p}$ values were significant at $1 \%$ level for e-service 
quality of public sector banks and information trust. The variables employees service quality and customer satisfaction were significant at $5 \%$ level. Performance of e-CRM is insignificant at $1 \%$ and $5 \%$ level. The DMRT test reveals that the diploma holders grouped with HSC and post graduates. It is also inferred that the undergraduate respondents grouped with professionals and significantly differ with the perception of other categories. Based on the mean scores, it is clear that the diploma and PG degree holders are higher than other groups. This may be due to the expectation of more services from the bank regarding employee's willingness to help, personalised services and safety for the transactions.

\section{Correlation analysis between respondent's online banking experience and Information Trust}

Correlation analysis was conducted in order to know the relationship between respondent's years of online banking experience and Information Trust

"H0: There is no significant relationship between respondent's years of online banking experience and Information Trust"

Table 5: Correlation Between Online Banking Experience and Information Trust

\begin{tabular}{|l|l|l|}
\hline \multirow{4}{*}{$\begin{array}{l}\text { Correlation between respondent's years of } \\
\text { online banking experience and Information } \\
\text { Trust }\end{array}$} & $\begin{array}{l}\text { Pearson } \\
\text { co-efficient }\end{array}$ & 0.027 \\
\cline { 2 - 3 } & Significance (2-tailed) & 0.746 \\
\cline { 2 - 3 } & $\mathrm{N}$ & 150 \\
\hline
\end{tabular}

It can be inferred from the above table that, the correlation co-efficient is 0.027 and the $p$ value is above 0.05 level. This shows that there no significant relationship between respondent's years of online banking experience and Information Trust.

\section{Multiple regression analysis}

Step-wise ordinal least square multiple regression analysis was conducted to find out the employees and e-service quality, customer satisfaction; information trust will serve as significant predictors and to explain the variance in performance of e-CRM.

"H0: There is no significant variation between employees and e-service quality, customer satisfaction, information trust to predict the performance of e-CRM"

Table 6 Variables in the Multiple Regression Analysis

\begin{tabular}{|c|c|c|c|c|}
\hline Study variables & e-CRM & perform & ince & Model summary \\
\hline & $\begin{array}{l}\text { B } \\
\text { Value }\end{array}$ & \begin{tabular}{|l|} 
T \\
Value \\
\end{tabular} & P value & \multirow{3}{*}{$\begin{array}{l}\mathrm{R}=0.667 ; \mathrm{R}^{2}=0.445 \\
\mathrm{~F}=.000 ; \mathrm{P}=0.000^{*}\end{array}$} \\
\hline (constant) & 0.547 & 1.852 & 0.66 & \\
\hline $\begin{array}{l}\text { Employees and e-service } \\
\text { quality }\end{array}$ & 0.838 & 10.893 & .000 & \\
\hline (constant) & 0.99 & 0.336 & .737 & \multirow{3}{*}{$\begin{array}{l}R=0.715 ; R^{2}=0.512 \\
F=.000 ; P=0.000^{*}\end{array}$} \\
\hline $\begin{array}{l}\text { Employees and e-service } \\
\text { quality }\end{array}$ & 0.650 & 7.778 & .000 & \\
\hline Customer satisfaction & 0.313 & 4.482 & .000 & \\
\hline (constant) & 0.21 & 0.71 & .944 & \multirow{4}{*}{$\begin{array}{l}R=0.727 ; R^{2}=0.528 \\
F=.000 ; P=0.027 * *\end{array}$} \\
\hline $\begin{array}{l}\text { Employees and e-service } \\
\text { quality }\end{array}$ & 0.566 & 6.254 & .000 & \\
\hline Customer satisfaction & 0.268 & 3.741 & .000 & \\
\hline Information Trust & 0.152 & 2.238 & .027 & \\
\hline
\end{tabular}

*denotes $1 \%$ significant level

$* *$ denotes $5 \%$ significant level

The above table explains the model summary and co-efficient of regression by taking employees and e-service quality, customer satisfaction, information trust as a predictor variable to explain its relationship towards e-CRM performance.

E-CRM performance as a dependent variable the step wise regression analysis resulted that $44.5 \%$ of e-CRM performance was explained by the variable employees and e-service quality with the correlation $\mathrm{R}=0.667, \mathrm{~F}=0.000, \mathrm{p}$ value $=0.000$ shows at $1 \%$ level of significance. In the next step $51.2 \%$ of e-CRM performance was explained by the variables customer satisfaction, employees and e-service quality with the correlation $\mathrm{R}=0.715$, $\mathrm{F}=0.000, \mathrm{p}$ value $=0.000$ shows at $1 \%$ level of significance. The final step shows that $52.8 \%$ of e-CRM performance was explained by the variables information trust, customer satisfaction, employees and e-service quality with the 
correlation $\mathrm{R}=0.72 .7, \mathrm{~F}=0.000, \mathrm{p}$ value $=0.027$ shows at $5 \%$ level of significance. Hence, the null hypothesis is rejected and it may be concluded that there is a significant variation between employees and e-service quality, customer satisfaction, information trust to predict the performance of e-CRM. The analysis of step-wise regression highlights the variation of information and it trusts to improve the e-CRM performance. The bank must ensure the reliability of service, information sharing and institute information to upgrade the performance level. "According to Yang, Y. F., \& Islam, M. 2009 the raising level of information trust to customer needs, a bank institution should provide online safety service, provide right and completed information to customer want, and internal and external system integration".

\section{Managerial implications}

The following points are the implications which has based on the empirical data. This study of data analysis is the solution seeking point and quintessence of the conclusion. There are umpteen and numerous challenges faced by current Indian Banking Industry (IBI) in the field of IT's system. In India, it is very common any banking systems have certain dilemmas to identify and satisfy the customers' contentment. Even though India possessed competitive advantages in IT enabled services in banking industry, yet these services need to be marketed in a proper way. The banks should adopt new innovative technologies with proper analysis of the mind of the customers. Simultaneously they should offer them the accurate products. There are three things which significant for considering the mind of the customers. They are mainly: products, procedures and processes. These three are indispensable views for the new sector. Moreover, it is based on feedback of the customers through by procedure and process of evaluating. By analysing the responses of customers it is revealed that, the performance of e-CRM in public sector banking is mainly depends on the information trust and customer satisfaction. It is the duty or responsible to augmenting the confidence level of customers about the benefits and security of the e-CRM services. The information security which would promote and extent to how the customers should use their own e-banking services. It may lead them to do the activities of banking process. At the same time, the banks should conduct the interaction programs with motivation for the customers to use appropriately the e- CRM services. This would definitely help to achieve the pinnacle point in the economic development and it helps obviously to reduce the wastage of paper by the way the ambience and vicinity will be preserved. The empirical result suggest that the banks should prepare a specific e-CRM policy to acquire more and more new customers and retain those customers for a longer period. R.K.Mittal \& Rajeeev., 2001 indicated that the "improve performance of e- CRM it is necessary for the public sector banks to develop strong \& flexible infrastructure, e-commerce capabilities, reduction of costs through higher productivity, lower complexity and automation of administrative functions with better products and services".

\section{Conclusion}

The present study found the outcomes and performance of e-CRM in the public sector banks from the customer's point of view. It proves the influence of age group of the respondents influences the number of times visited bank and transactions made in a month. The educational level of customers plays a significant role towards the perception of e-CRM practices, e-service quality and customer satisfaction except in the case of e-CRM performance. Step-wise multiple regression analysis reveals that information trust is the only factor influencing more towards the e-CRM performance of banks. So the banks have to ensure the reliability of service, information sharing, online safety service, providing right and completed information to customer needs and wants with respect to internal and external system 
integration. However, "more number of researches needs to be done using random samples from both banks as well as other sectors to determine the association between deployment of e-CRM practices, customer satisfaction and information trust of profitable retail customers".

\section{References}

[1] Abu-Shanab, E., \& Anagreh, L. (2015). Impact of electronic customer relationship management in banking sector. International Journal of Electronic Customer Relationship Management, 9(4), 254-270.

[2] Abu-Shanab, E., \& Anagreh, L. (2015). Impact of electronic customer relationship management in banking sector. International Journal of Electronic Customer Relationship Management, 9(4), 254-270.

[3] Agariya, A. K., \& Singh, D. (2012). CRM Index development and validation in Indian banking sector. International Journal of Customer Relationship Marketing and Management (IJCRMM), 3(2), 10-32.

[4] Al-Refaie, A., Tahat, M. D. A., \& Bata, N. (2014). CRM/e-CRM effects on banks performance and customer-bank relationship quality. International Journal of Enterprise Information Systems (IJEIS), 10(2), 62-80.

[5] Anderson, W. O. (2001, October). Customer relationship management in an e-business environment. In IEMC'01 Proceedings. Change Management and the New Industrial Revolution. IEMC-2001 (Cat. No. 01CH37286) (pp. 311-316). IEEE.

[6] Arora, M. E. E. R. A. "Role of Service Quality in Customer Relationship Management: An Empirical Study of Indian Telecom Industry." Research and Development (IJSMMRD) 3.2 (2013): 87-94.

[7] Ashford, N. A., \& Hall, R. P. (2011).
Technology, globalization, and sustainable development: Transforming the industrial state. Yale University Press.

[8] Azila, N., \& Noor Neeraj, M. (2011). Electronic Customer Relationship Management Performance: Its Impact on Loyalty From Customers' Perspe-ctives. International Journal of e-Education, e-Business, e-Management and e-Learning, 1(1), 1.

[9] Balachandra, P., Nathan, H. S. K., \& Reddy, B. S. (2010). Commercialization of sustainable energy technologies. Renewable Energy, 35(8), 1842-1851.

[10]Bantel, K. A., \& Jackson, S. E. (1989). Top management and innovations in banking: does the composition of the top team make a difference?. Strategic management journal, 10(S1), 107-124.

[11]Chen, I. J., \& Popovich, K. (2003). Understanding customer relationship management (CRM) People, process and technology. Business process management journal, 9(5), 672-688.

[12]Cho, Y., Im, I., Hiltz, R., \& Fjermestad, J. (2002, January). An analysis of online customer complaints: implications for web complaint management. In Proceedings of the 35th Annual Hawaii International Conference on System Sciences (pp. 2308-2317). IEEE.

[13]Chopra, B., Bhambri, V., \& Krishan, B. (2012). E-CRM-A new paradigm for managing customers. International Journal of Research in Engineering \& Applied Sciences, 2(2), 1163-1174.

[14] Darajeh, M. R., \& Tahajod, M. (2010, June). Benefits of e-CRM for financial services providers. In 2010 International Conference on Financial Theory and Engineering (pp. 95-98). IEEE. 
[15]Das, S. (2012). Customer relationship management in banking sector: a comparative study of SBI and other nationalized commercial banks in India. Journal of Economics and Management (APJEM) Volume, 1, 2278-0629

[16]Das, S. K. (2012). Customer relationship management in banking sector: a comparative study of SBI and other nationalized commercial banks in India. Journal of Economics and Management (APJEM), Vol, 1, 2278-0629.

[17]Dhingra, M., \& Dhingra, V. (2013). Determinants of Electronic customer relationship management (e-CRM) for customer satisfaction in banking sector in India. African Journal of Business Management, 7(10), 762-768.

[18]Dhingra, M., \& Dhingra, V. (2013). Determinants of Electronic customer relationship management (e-CRM) for customer satisfaction in banking sector in India. African Journal of Business Management, 7(10), 762-768.

[19]El Essawi, N., \& El Aziz, R. A. (2012). Determining the main dimensions that affect e-customer relationship management readiness in the Egyptian banking industry. International Journal of Electronic Customer Relationship Management, 6(3-4), 217-234.

[20]Foss, B. - CRM in Financial Services: A Practical Guide to Making CustomerRelationship Management Workl Milford, CT, USA, Kogan Page Ltd, 2002.

[21] Gebert, H., Geib, M., Kolbe, L., \& Brenner, W. (2003). Knowledge-enabled customer relationship management: integrating customer relationship management and knowledge management concepts. Journal of knowledge management, 7(5), 107-123.
[22] Geib, M., Reichold, A., Kolbe, L., \& Brenner, W. (2005, January). Architecture for customer relationship management approaches in financial services. In System Sciences, 2005. HICSS'05. Proceedings of the 38th Annual Hawaii International Conference (pp. 240b-240b). IEEE.

[23] Giannakis-Bompolis, C., \& Boutsouki, C. (2014). Customer relationship management in the era of social web and social customer: an investigation of customer engagement in the Greek retail banking sector. Procedia-Social and Behavioral Sciences, 148, 67-78.

[24]Greeshma, S. (2016). A Study on Electronic Customer Relationship Management Initiatives of ICICI Bank. International Journal of Latest Trends in Engineering and Technology, Spl Issue (SACAIM - 2016), 466-473.

[25]Grover, D. (2011). Effective customer relationship management through e-CRM. Viewpoint, 2, 27-38.

[26]Harrigan, P., Ramsey, E., \& Ibbotson, P. (2012). Exploring and explaining SME marketing: investigating e-CRM using a mixed methods approach. Journal of Strategic Marketing, 20(2), 127-163.

[27]Hendriyani, C., \& Raharja, S. U. J. (2018). Analysis building customer engagement through e-CRM in the era of digital banking in Indonesia. International Journal of Economic Policy in Emerging Economies, 11(5), 479-486.

[28]Hong-kit Yim, F., Anderson, R. E., \& Swaminathan, S. (2004). Customer relationship management: Its dimensions and effect on customer outcomes. Journal of Personal Selling \& Sales Management, 24(4), 263-278.

[29]Karakostas, B., Kardaras, D., \& 
Papathanassiou, E. (2005). The state of CRM adoption by the financial services in the UK: an empirical investigation. Information \& Management, 42(6), 853-863.

[30] Karakostas, B., Kardaras, D., \& Papathanassiou, E. (2005). The state of CRM adoption by the financial services in the UK: an empirical investigation. Information \& Management, 42(6), 853-863.

[31] Kaur, J., \& Kaur, B. (2016). The Influence of e-CRM Competitive Advantage on e-CRM Performance in the Indian Banking Industry. Strategic Change, 25(5), 537-550.

[32] Kennedy, A. (2006). Electronic customer relationship management (eCRM): Opportunities and challenges in a digital world.

[33] Khare, A. (2010). Online banking in India: An approach to establish CRM. Journal of Financial Services Marketing, 15(2), 176-188.

[34] Khare, A. (2010). Online banking in India: An approach to establish CRM. Journal of Financial Services Marketing, 15(2), 176-188.

[35] Khasawneh, R., \& Abu-Shanab, E. (2012). Electronic customer relationship management (e-CRM) in Jordan: the case of Egyptian Arab Land Bank. International Journal of Technology Diffusion (IJTD), 3(3), 36-46.

[36] Kımıloğlu, H., \& Zaralı, H. (2009). What signifies success in e-CRM?. Marketing intelligence \& planning, 27(2), 246-267.

[37] Kumra, R., \& Mittal, R. K. (2004). Trust and its Determinants in Internet Banking: A Study of Private Sector Banks in India. Decision (0304-0941), 31(1).

[38]KUMAR, BRIJESH. "MODALITIES OF DIAGNOSIS \& MANAGEMENT OF SMALL BLUE ROUND CELL TUMOR." International Journal of Medicine and
Pharmaceutical Science (IJMPS) ISSN (P): 2250-0049; ISSN (E): 2321-0095 Vol. 9, Issue 5, Oct 2019, 1-6

[39]Lee, J., Lee, J., \& Feick, L. (2001). The impact of switching costs on the customer satisfaction-loyalty link: mobile phone service in France. Journal of services marketing, 15(1), $35-48$.

[40]Leventhal, R. C., \& Zineldin, M. (2006). The royalty of loyalty: CRM, quality and retention. Journal of consumer marketing.

[41]Ling, R., \& Yen, D. C. (2001). Customer relationship management: An analysis framework and implementation strategies. Journal of computer information systems, 41(3), 82-97.

[42]Manoj, P. K., \& Joju, J. (2014). Impact of e-crm on commercial banking: an empirical investigation with reference to private sector banks in Kerala. International Journal of Applied Services Marketing Perspectives, 3(3), 1120.

[43] Mittal, R. K., \& Kumra, R. (2001). e-CRM in Indian banks. Delhi business review, 2(1), 73-78.

[44]Mittal, R. K., \& Kumra, R. (2001). e-CRM in Indian banks. Delhi business review, 2(1), 73-78.

[45]Mnjala, D. M. (2014). The challenges of creating sustainable competitive advantage in the banking industry in Kenya. Journal of Business and Management, 16(4), 82-87.

[46] Navimipour, N. J., \& Soltani, Z. (2016). The impact of cost, technology acceptance and employees' satisfaction on the effectiveness of the electronic customer relationship management systems. Computers in Human Behaviour, 55, 1052-1066.

[47]Ngai, E. W. (2005). Customer relationship 
management research (1992-2002) An academic literature review and classification. Marketing intelligence \& planning, 23(6), 582-605.

[48] Nippatlapalli, A. R. (2013). A study on customer satisfaction of commercial banks: Case study on State Bank of India. IOSR Journal of Business and Management, 15(1), 60-86.

[49] Onut, S., Erdem, I., and Hosver, B. Customer Relationship Management in Banking Sector and A Model Design for Banking Performance Enhancement, Yildiz Technical University, Istanbul, Turkey ,2006.

[50] Oumar, T. K., Mang'Unyi, E. E., Govender, K. K., \& Rajkaran, S. (2017). Exploring the e-CRM-e-customer-e-loyalty nexus: a Kenyan commercial bank case study. Management \& Marketing, 12(4), 674-696.

[51]Pan, S. L., \& Lee, J. N. (2003). Using e-CRM for a unified view of the customer. Communications of the ACM, 46(4), 95-99.

[52]Pan, S. L., \& Lee, J. N. (2003). Using e-CRM for a unified view of the customer. Communications of the ACM, 46(4), 95-99.

[53]Pan, S. L., Tan, C. W., \& Lim, E. T. (2006). Customer relationship management (CRM) in e-government: a relational perspective. Decision support systems, 42(1), 237-250.

[54]Payne, A., \& Frow, P. (2013). Strategic customer management: Integrating relationship marketing and CRM. Cambridge University Press.

[55]Peppard, J. (2000). Customer relationship management (CRM) in financial services. European Management Journal, 18(3), 312-327.

[56]Rahman, Z. (2006). Customer experience management - A case study of an Indian bank.
Journal of Database Marketing \& Customer Strategy Management, 13(3), 203-221.

[57]Rajendiran, P., et al. "Customer Relationship Management in the Manufacturing Industry, Using Data Mining Techniques." International Journal of Educational Science and Research (IJESR) 7. 6, Dec 2017, 63-70

[58]Rashid Farooqu, Md., Sharda Kumari., \& Mohad, Shoeb. (2013). Recent Trend of e-CRM in CommercialBanks of India. International Journal of Application or Innovation in Engineering \& Management (IJAIEM), 2(4), 287-291.

[59]Romano Jr, N. C., \& Fjermestad, J. (2007). Privacy and security in the age of electronic customer relationship management. International Journal of Information Security and Privacy (IJISP), 1(1), 65-86.

[60]Sandeep Walunj., \& Barhate G. (2014). E-CRM in India Bank: Differentiating Tool in Competitive Market. IBMRD's Journal of Management and Research, 3(1), 258-268.

[61]Schmitt, B. H. (2010). Customer experience management: A revolutionary approach to connecting with your customers. John Wiley $\&$ Sons.

[62]Sivaraks, P., Krairit, D., \& Tang, J. C. (2011).Effects of e-CRM on customer-bank relationship quality and outcomes: The case of Thailand. The Journal of High Technology Management Research, 22(2), 141-157.

[63]Slater, S. F., \& Mohr, J. J. (2006). Successful development and commercialization of technological innovation: Insights based on strategy type. Journal of product innovation management, 23(1), 26-33.

[64]Shukla, Neha. "Social Media \& Its Influence on Customer Relationship in Indian Retail Scenario." International Journal of Sales \& Marketing Management Research and 
Development (IJSMMRD)7.4, Aug 2017, $27-$ 34

[65] Stefanou, C. J., Sarmaniotis, C., \& Stafyla, A. (2003). CRM and customer-centric knowledge management: an empirical research. Business Process Management Journal, 9(5), 617-634.

[66] Teo, T. S., Devadoss, P., \& Pan, S. L. (2006). Towards a holistic perspective of customer relationship management (CRM) implementation: A case study of the Housing and Development Board, Singapore. Decision support systems, 42(3), 1613-1627.

[67] Van Weele, A. J., \& Rozemeijer, F. A. (1996). Revolution in purchasing: Building competitive power through proactive. European Journal of Purchasing \& Supply Management, 2(4), 153-160.

[68] Wu, I. L., \& Wu, K. W. (2005). A hybrid technology acceptance approach for exploring e-CRM adoption in organizations. Behaviour \& Information Technology, 24(4), 303-316

[69]Wu, I. L., \& Wu, K. W. (2005). A hybrid technology acceptance approach for exploring e-CRM adoption in organizations. Behaviour \& Information Technology, 24(4), 303-316.

[70]Xu, M., \& Walton, J. (2005). Gaining customer knowledge through analytical CRM. Industrial management \& data systems, 105(7), 955-971.

[71]Xu, M., \& Walton, J. (2005). Gaining customer knowledge through analytical CRM. Industrial management \& data systems, 105(7), 955-971.

[72]Xu, Y., Yen, D. C., Lin, B., \& Chou, D. C. (2002). Adopting customer relationship management technology. Industrial management \& data systems, 102(8), 442-452.
[73] Yang, Y. F., \& Islam, M. (2009). Service satisfaction, information trust and e-crm performance in BSC model in empirics of financial institutions. Research yearbook, 490.

[74]Zablah, Alex R., Bellenger, Danny N., and Johnston, Wesley J.,(2004) “An Evaluation of Divergent perspectives on Customer Relationship Management: towards a Common Understanding of an Emerging Phenomenon", Industrial Marketing Management, 33(6), pp.475-489.

[75]Zeleke, Simachew, and Dr A. Prabhu Kumar. "Understanding the Customer Relationship Management (CRM) Scenario in the Hotel Industry: A Systematic." International Journal of Sales \& Marketing Management Research and Development (IJSMMRD) 9.2, Dec 2019, 23-36

[76]Zineldin, M. (1995). Bank-company interactions and relationships: some empirical evidence. International Journal of Bank 